\title{
Atmospheric Pollutants Assessment during the COVID-19 Lockdown Using Remote Sensing and Ground-based Measurements in Buenos Aires, Argentina
}

Special Issue:

Special Issue on COVID-19 Aerosol Drivers, Impacts and Mitigation (XI)

\author{
Natacha S. Represa ${ }^{1 *}$, Lara S. Della Ceca ${ }^{1}$, Gabriela Abril ${ }^{2}$, \\ María F. García Ferreyra ${ }^{1}$, Carlos M. Scavuzzo ${ }^{1}$ \\ ${ }^{1}$ Instituto de Altos Estudios Espaciales Mario Gulich (IG), Comisión Nacional de Actividades \\ Espaciales (CONAE), Ruta C45. Km 8. CP 5187 - Falda del Cañete, Córdoba, Argentina \\ ${ }^{2}$ Autoridad de Cuenca Matanza Riachuelo (ACUMAR). Esmeralda 255, CP C1035ABE - Ciudad \\ Autónoma de Buenos Aires, Argentina
}

\section{ABSTRACT}

The COVID-19 outbreak measures of lockdown have generated exceptional urban behavior conditions allowing the analysis of a unique scenario. We examined the atmospheric emissions in Buenos Aires, Argentina, based on urban and industrial continuous monitoring of $\mathrm{NO}_{2}, \mathrm{PM}_{10}$ and $\mathrm{PM}_{2.5}$, and $\mathrm{NO}_{2}$ (TROPOMI/Sentinel-5p) and AOD (MAIAC/MODIS, Aqua) satellite products, in addition with meteorological data. We considered the time intervals before and after the announcement of lockdown, including the same periods for 2019. The results showed that $\mathrm{NO}_{2}$ and $\mathrm{PM}_{10}$ concentrations fell by $\sim 30 \%$ and $44 \%$, respectively, at urban stations during lockdown compared to 2019. An increase in PM at the industrial station (64\% $\mathrm{PM}_{2.5}$ and $\left.8 \% \mathrm{PM}_{10}\right)$ could be due to the contribution of industrial sources other than vehicle traffic. Also, we observed a reduction of the tropospheric $\mathrm{NO}_{2}$ column density mean by $54 \%$ at urban stations, and $A O D$ values decreased between $38 \%$ and $66 \%$ during 2020 . Concerning the spatial distribution, the tropospheric $\mathrm{NO}_{2}$ column showed a significant reduction of $\mathrm{NO}_{2}$ for the monthly mean in the metropolitan area at lockdown. Similarly, the AOD highest values had a greater extension for 2020 during the prelockdown monthly period. After the strict lockdown, concentration values increased steadily, particularly in ground-based measurements. Therefore, we were able to demonstrate the complementarity of ground-based and satellite data measurements of $\mathrm{NO}_{2}$ and aerosol to identify the effects of lockdown measures on the spatial and temporal variability of pollutants.

Received: May 15, 2020

Revised: June 6, 2020

Accepted: December 25, 2020

Keywords: COVID-19, Air quality, Lockdown, Remote sensing, Ground-based monitoring

\section{${ }^{*}$ Corresponding Author:}

solrepresa@quimica.unlp.edu.ar

\section{INTRODUCTION}

Publisher:

Taiwan Association for Aerosol Research

ISSN: $1680-8584$ print ISSN: 2071-1409 online

(c) Copyright: The Author(s). This is an open access article distributed under the terms of the Creative Commons Attribution License (CC BY 4.0), which permits unrestricted use, distribution, and reproduction in any medium, provided the original author and source are cited.

Air pollution is considered the world's largest environmental health threat, accounting for 7 million deaths worldwide every year (Mannucci and Franchini, 2017). Atmospheric pollutant exposure is the most critical risk factor for major non-communicable diseases (Cohen et al., 2017). Chronic exposure at high levels of air pollutants contributes to the occurrence of heart disease, respiratory system disorders, and cancer (Schwela, 2000). Also, poor air quality is linked to respiratory failure, premature pregnancy, and the development of respiratory allergies (WHO, 2010; Goldstone, 2015).

Nitrogen dioxide $\left(\mathrm{NO}_{2}\right)$ and particulate matter $(\mathrm{PM})$ are considered criteria atmospheric pollutants that require monitoring to preserve the public health. $\mathrm{NO}_{2}$ is an air quality indicator of combustion emissions (mostly fossil fuel combustion from vehicles and power plants) associated with respiratory morbidity and mortality (Burnett et al., 2004; Samoli et al., 2006; Brunekreef, 2008; U.S. EPA, 2008). This gas is an important driver of air quality degradation in urban/industrialized 
centers. It contributes to the tropospheric ozone formation and is a precursor to secondary inorganic aerosols that have consequences for climate and human health (Lelieveld et al., 2015; Atkinson et al., 2018; Bauwens et al., 2020). PM enters the atmosphere from natural sources as desert dust, forest fires, sea salt, and sulphates from volcanoes, but the expanding human activity has increased the PM burden (Zhang et al., 2015). Large cities with higher traffic and poor air pollutant dispersion are more susceptible to adverse health effects (Atkinson et al., 2010; Dongarra et al., 2010; Correia et al., 2013; Cadelis et al., 2014; Mukherjee and Agrawal, 2017).

The Metropolitan Area of Buenos Aires (AMBA) is one of the most critical regions of Latin America, with more than 16 million inhabitants (INDEC, 2011). Its population grew sustained during the 20th and early 21st centuries, with an acceleration by industrialization from 1940 to 1960 (Camilloni and Barrucand, 2012). AMBA is one of the few places in Argentina that air quality is monitored using ground-stations. Previous studies show levels of atmospheric pollutants exceed WHO air quality guidelines, exposing the population to risk (Abrutzky et al., 2013; Ferreroa et al., 2019; Represa, 2020).

In addition to local ground-based monitoring, pollution may be monitored using remote sensing (Duncan et al., 2014). The TROPOspheric Monitoring Instrument (TROPOMI) sensor onboard the Copernicus Sentinel-5P (S5P) satellite, launched in October 2017 by the European Space Agency (ESA), retrieves daily gaseous species levels with a resolution of $5.6 \times 3.5 \mathrm{~km}$ (Veefkind et al., 2012). Besides, the aerosol optical depth (AOD) is a parameter obtained by remote sensing linked to airborne particles' presence. Moderate Resolution Imaging Spectroradiometer (MODIS) provided a daily AOD product with a spatial resolution of $1 \mathrm{~km}$ (Lyapustin et al., 2011a, b).

In front of the events that are public knowledge, the SARS-CoV-2 virus outbreak has forced governments to take unprecedented measures to prevent its spread. The acute respiratory disease caused by the virus, known as COVID-19, has been declared a public health emergency of international concern by the World Health Organization (WHO, 2020) given its high rate of transmission. It can cause severe illness, particularly in patients with pre-existing respiratory problems (Bai et al., 2020). Fear of the collapse of the health system has led many countries to take different actions to reduce social contact, including travel restrictions, curfews, and quarantines.

The first Argentinean case of coronavirus was detected on March $5^{\text {th }}$ and the first national policy action was taken on March $20^{\text {th }}$ (Ministerio de Salud, 2020). The lockdown was then extended, with fortnightly modifications, to continue the propagation rhythm. The quarantine initially covered the AMBA territory, while social distancing measures were quickly taken throughout the country. As an exception, some urban areas that registered a high level of infections, such as AMBA, have returned to the initial phase 1 , a stricter lockdown.

The disruption in daily activity generated a unique scenario to evaluate the effect on air quality by reducing vehicle traffic, one of the main sources of urban pollution. Therefore, the purposes of this work were to evaluate changes in air pollutant concentrations in AMBA and Buenos Aires' City (CABA) during the lockdown and assess ground-based and satellite measurements' ability to describe exceptional situations.

\section{MATERIALS AND METHODS}

AMBA is located around $35^{\circ} \mathrm{S}$ along the western coast of the Río de la Plata estuary. The metropolitan area extends for $4000 \mathrm{~km}^{2}$, and its surface is featureless with only minor differences in the height of less than $30 \mathrm{~m}$ (Fig. 1)

The lockdown period analyzed ranged from March $20^{\text {th }}-$ May $14^{\text {th }}$. During this timeframe, different restrictions were established, being stricter at first with few activities allowed. With the long Easter weekend in between, the country intensified the reinforcement of vehicle controls. Especially, half of the accesses to CABA were closed, which was the epicenter of the pandemic in Argentina. By the end of the period studied (April-May), restrictions for some activities were gradually lifted and recreational outings were allowed.

We considered the periods before and after the closure announcement, including the same periods for 2019, to assess whether the lockdown restrictions had a positive impact on the region's air quality. For meteorological data and ground-based pollutants, weekly mean concentrations were 


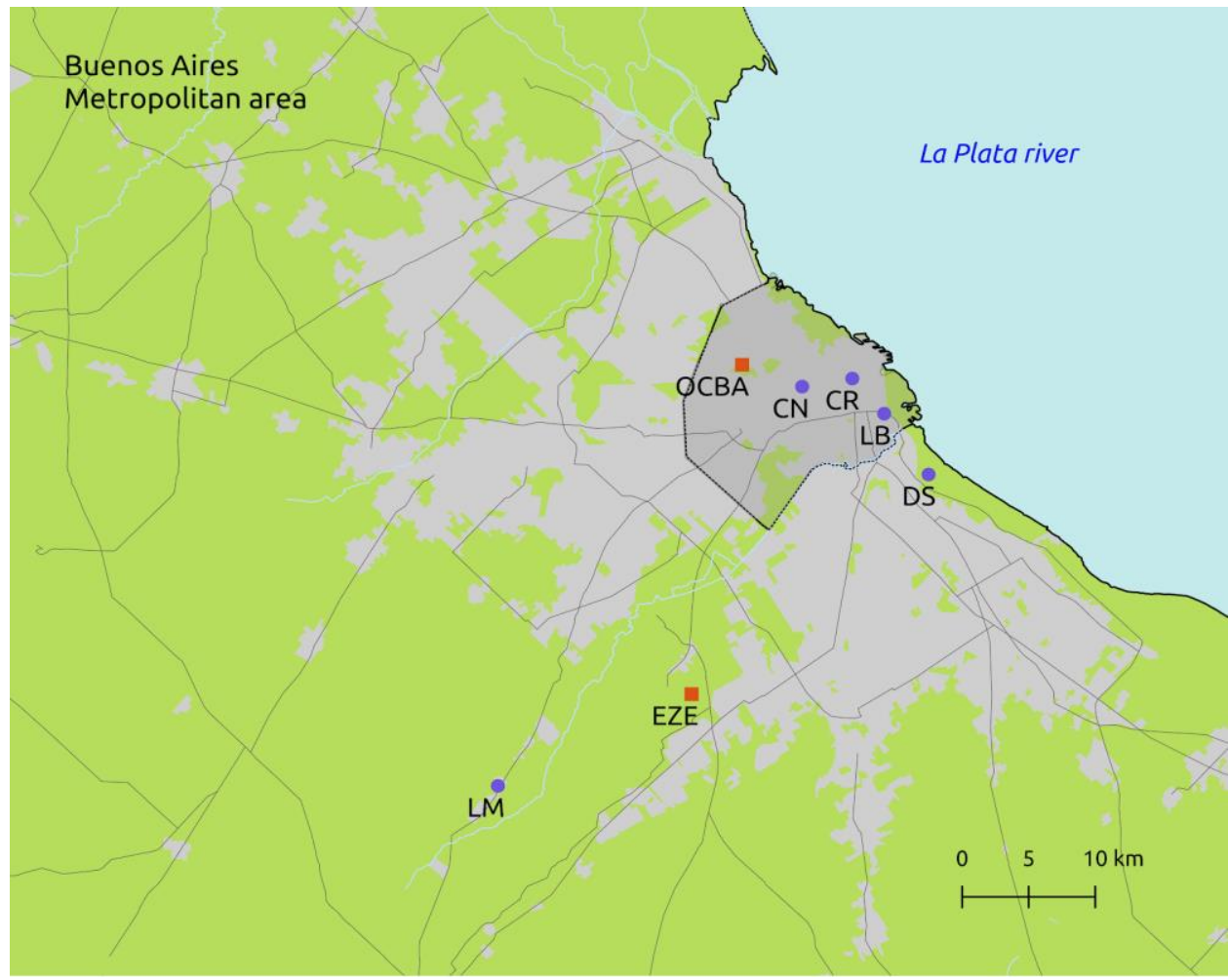

Fig. 1. Map of Buenos Aires and the Metropolitan area. Red squares indicate weather stations Central Observatory of Buenos Aires (OCBA) and Ezeiza (EZE). Blue dots indicate the Dock Sud (DS), La Matanza (LM), Centenario (CN), Cordoba (CR) and La Boca (LB) ground-based monitoring stations.

calculated from January $24^{\text {th }}$ to May $14^{\text {th }}$, for both years. Meanwhile, we analyzed satellite data in fortnightly average periods. $\mathrm{NO}_{2}$ and $\mathrm{AOD}$ maps were built from monthly means before and after the announcement of lockdown date (February $19^{\text {th }}-$ March $19^{\text {th }}$ and March $20^{\text {th }}-$ April $20^{\text {th }}$, respectively), for both years.

\subsection{Traffic Flow}

As an indicator of urban activity during the lockdown period, we analyzed the data regarding the traffic flow registered in toll stations in CABA. Radar data was provided by Autopistas Urbanas S.A. (https://data.buenosaires.gob.ar/). The data period available was from January 24 th to March $30^{\text {th }}, 2019$, and 2020.

\subsection{Meteorological Data}

Hourly meteorological data (temperature, wind direction, and precipitation) were obtained from the Argentinian Weather Service (SMN) and NCEI data (https://www.ncei.noaa.gov/). The SMN has two meteorological stations in the study area: Central Observatory of Buenos Aires station (OCBA - ID 87585) located in CABA near the urban area, and Ezeiza station (EZE - ID 87576) located at the International Airport in AMBA, 28 km apart (Fig. 1).

\subsection{Ground-measurements}

$\mathrm{PM}_{10}, \mathrm{PM}_{2.5}$ and $\mathrm{NO}_{2}$ data were acquired from five ground-monitoring stations of air quality (Fig. 1). Three of these stations are located at CABA and are managed by the Buenos Aires Environmental Protection Agency (APrA): Parque Centenario (CN), Cordoba (CR) and La Boca (LB). The remaining two are located at AMBA and are administered by the Matanza-Riachuelo Basin Authority (ACUMAR): Dock Sud (DS) and La Matanza (LM). Below is a brief characterization for each of them:

* $\mathrm{CN}$ is in a residential-commercial area with a medium vehicular flow and very low incidence of 
fixed sources. It is next to a public green space located in the geographic center of CABA.

* $\mathrm{CR}$ is in a residential-commercial area, at the intersection of two ample avenues with high vehicular flow and very low incidence of fixed sources.

* LB is in a mixed zone about La Boca, southeast from CABA, within the influence area of the Matanza-Riachuelo basin. It has medium-low vehicular flow and incidence of fixed sources. It is $3 \mathrm{~km}$ away from the Dock Sud.

* DS is at Dock Sud where the port facility operates. It has one of the most important container terminals in the country, and several industries are installed in the area (refineries, fuel storage, thermoelectric, and waste management plants). The activity at Dock Sud in the quarantine continued for the main industries installed in the area.

* LM is at La Matanza, which is the most populous and largest district in the entire country with $325.71 \mathrm{~km}^{2}$ (INDEC, 2011). Diverse industries (food, automotive, chemical, and construction industries) are located near this monitoring site. It is $500 \mathrm{~m}$ away from the National Route $\mathrm{N}^{\circ}$ 3 where heavy and light-duty vehicles circulate continuously. As reported by ACUMAR, the activity of the food and chemical industries was regular, yet the closest automotive and construction industries were not working during the lockdown.

$\mathrm{NO}_{2}$ was measured continuously through chemiluminescence (EPA Automated Reference Method). CR and LB APrA monitoring stations are equipped with Monitor Labs analyzers (ML 9841B - detection limit: $0.40 \mathrm{ppb}$ ), whereas CN station has a Thermo Scientific Monitor (Thermo $42 \mathrm{C}$ - detection limit: $0.40 \mathrm{ppb}$ ). APrA agency provided hourly data expressed in ppb, which was converted to $\mu \mathrm{g} \mathrm{m}^{-3}$. Regarding ACUMAR monitoring stations, DS measures with an Environment Monitor (AC32 M - detection limit: $0.40 \mathrm{ppb}$ ) and LM with an Ecotech analyzers (Serinus 40 detection limit: $<0.40 \mathrm{ppb}$ ). ACUMAR provided hourly data expressed in $\mu \mathrm{g} \mathrm{m}^{-3}$.

$\mathrm{PM}_{10}$ and $\mathrm{PM}_{2.5}$ were measured continuously through the $\beta$-attenuation monitoring technique (EPA Automated Equivalent Method). CABA monitoring stations are equipped with Thermo Scientific Continuous Particulate Monitors for PM 10 (FH62C14 - detection limit: < $1 \mu \mathrm{g} \mathrm{m}^{-3}$ 24-h average). APrA agency provided 24-hour moving average data in $\mu \mathrm{g} \mathrm{m}^{-3}$. As for ACUMAR monitoring stations, DS measures $\mathrm{PM}_{10}$ and $\mathrm{PM}_{2.5}$ with an Environnement Continuous Particulate Monitor (MP101M LCD and CPM - detection limit: $0.5 \mu \mathrm{g} \mathrm{m}^{-3}$ 24-h average), and LM with an Ecotech Continuous Particulate Monitor for $\mathrm{PM}_{10}$ and $\mathrm{PM}_{2.5}$ (Spirant BAM1000 and 1100 detection limit: $<1 \mu \mathrm{g} \mathrm{m}^{-3} 24$-h average). ACUMAR provided hourly data expressed in $\mu \mathrm{g} \mathrm{m}^{-3}$, and the 24-hour moving averages were then calculated.

\subsection{Satellite Measurements}

$\mathrm{NO}_{2}$ satellite-based measurements were obtained from sensor TROPOMI onboard Sentinel-5p (ESA). We used daily tropospheric $\mathrm{NO}_{2}$ column number density product (OFFL_NO2 L3, https://sentinels.copernicus.eu/), filtered by the quality assurance $>0.5$ to obtain 2-week and monthly mean and standard deviation values within the study area. For atmospheric aerosols, we utilized MODIS/Aqua AOD product recovered with the Multi-angle Implementation of Atmospheric Correction (Lyapustin et al., 2011a, Archive Center (LP DAAC) Distribution Server (https://Ipdaac.usgs.gov/). Aqua satellite overpasses AMBA between 13-17 h (local time). Daily AOD was filtered by the quality band to ensure maximum data quality and no cloud interference. We calculated 2-week periods, monthly means and standard deviations, considering before and after the announcement of lockdown dates, for 2019 and 2020.

\section{RESULTS AND DISCUSSION}

\subsection{Traffic}

As mentioned, CABA and AMBA concentrate a large part of the country's economic activities. This singularity generates significant vehicular traffic that affects air quality. In 2019, the total car park for CABA reached 1.496.711 vehicles (passenger cars and pickups, light commercial vehicles, trucks, and buses) and, on average, the number of vehicles passing through the City's radars is between 2 and 3 thousand in ordinary weeks. Fig. 2 shows the normal fluctuations in vehicle traffic and the sudden drop due to mandatory social isolation. The marked decrease indicates the interruption of vehicular traffic as a source of pollutant emission into the atmosphere. 

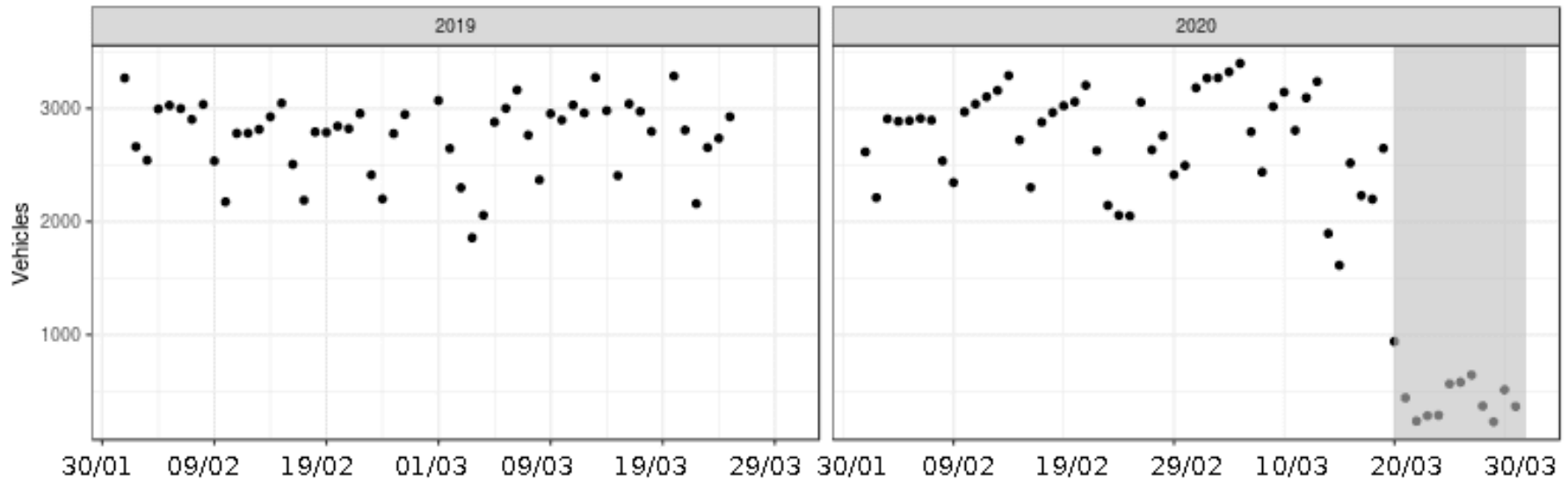

Fig. 2. Daily average of vehicles circulating on the main highways and avenues of the City of Buenos Aires. The start of the quarantine period is highlighted in gray.

Table 1. Monthly mean of temperature (T), wind speed (WS), and precipitation ( $p$ ) at Central Observatory of Buenos Aires (OCBA) and Ezeiza (EZE) meteorological stations.

\begin{tabular}{|c|c|c|c|c|c|c|}
\hline \multirow{2}{*}{ Month } & \multicolumn{3}{|c|}{2019} & \multicolumn{3}{|c|}{2020} \\
\hline & $\mathrm{T}\left({ }^{\circ} \mathrm{C}\right)$ & WS $\left(\mathrm{km} \mathrm{h}^{-1}\right)$ & $p(m m)$ & $\mathrm{T}\left({ }^{\circ} \mathrm{C}\right)$ & WS $\left(\mathrm{km} \mathrm{h}^{-1}\right)$ & $p(m m)$ \\
\hline \multicolumn{7}{|l|}{ OCBA } \\
\hline Feb & $24.3 \pm 5.0$ & $7.9 \pm 5.1$ & 47.4 & $24.4 \pm 4.7$ & $8.5 \pm 5.0$ & 66.2 \\
\hline Mar & $21.1 \pm 4.2$ & $7.9 \pm 5.1$ & 104.0 & $24.1 \pm 3.7$ & $7.8 \pm 4.7$ & 158.3 \\
\hline Apr & $19.3 \pm 3.4$ & $7.1 \pm 4.7$ & 51.2 & $18.0 \pm 3.8$ & $8.1 \pm 5.3$ & 87.2 \\
\hline May & $16.3 \pm 3.6$ & $8.2 \pm 4.9$ & 75.5 & $15.7 \pm 4.0$ & $8.9 \pm 6.4$ & 22.6 \\
\hline \multicolumn{7}{|l|}{ EZE } \\
\hline Feb & $22.3 \pm 5.6$ & $11.1 \pm 6.6$ & 48.8 & $23.3 \pm 5.5$ & $11.9 \pm 6.4$ & 149.5 \\
\hline Mar & $19.6 \pm 5.0$ & $12.2 \pm 7.2$ & 208.8 & $23.0 \pm 4.4$ & $11.1 \pm 5.7$ & 198.0 \\
\hline Apr & $17.5 \pm 4.9$ & $10.6 \pm 6.7$ & 26.7 & $16.8 \pm 4.6$ & $11.4 \pm 7.1$ & 205.9 \\
\hline May & $14.1 \pm 4.6$ & $11.8 \pm 6.4$ & 77.4 & $14.4 \pm 4.6$ & $11.9 \pm 6.9$ & 9.6 \\
\hline
\end{tabular}

\subsection{Meteorological Conditions}

Weather conditions are an essential aspect considering their strong influence on air quality (Borge et al., 2019; Collivignarelli et al., 2020). Monthly averages obtained by hourly measurements of temperature and wind speed at OCBA and EZE showed no significant differences among monthly data from January to May 2019 and 2020. OCBA station had higher temperatures and lower wind speeds than EZE, for the whole period. The latter year underwent a rainier season, mainly at EZE station (Table 1).

\subsection{Ground Measurements}

Initially, we analyzed the situation before the cessation of activities (Fig. 3). In general, the first fraction of the period studied showed comparatively lower concentrations than the second one for both years (Table S1). This difference could be caused by the higher temperatures from the summer season that facilitate pollutant dispersion (Seinfeld and Pandis, 2016). Likewise, summer vacations may be another factor influencing these low concentration values.

Except for $\mathrm{PM}_{10}$ and $\mathrm{PM}_{2.5}$ at LM, concentrations in 2020 were lower than in 2019 for the first period. This difference may be attributed to the rainy season. The $\mathrm{NO}_{2}$ concentration had a reduction of $49 \%>38 \%>13 \%>2.3 \%$ for $L M, C R$, LB and CN. We observed for $\mathrm{PM}_{10}$ concentration values a reduction of $71 \%>33 \%>14 \%>7 \%$ in $\mathrm{LB}, \mathrm{CR}, \mathrm{CN}$, and DS. PM 2.5 was $8 \%$ lower in DS. We saw an increase of $32 \%$ for $\mathrm{PM}_{10}$ and $54 \%$ for $\mathrm{PM}_{2.5}$ for the first annual period at $L M$.

At the beginning of the quarantine, contaminants decreased notably, reaching the minimum concentration values within the initial weeks of lockdown (Fig. 3). This reduction was observed in all pollutants, varying in the magnitude of the fall. The exception has also been the LM station, 

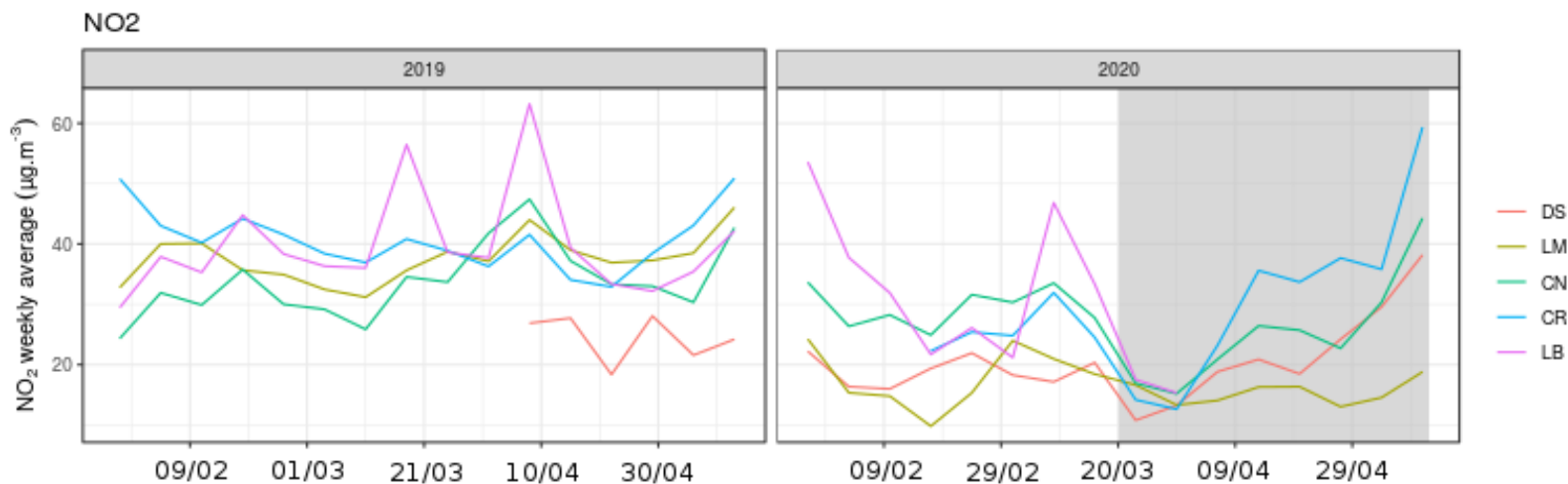

PM10
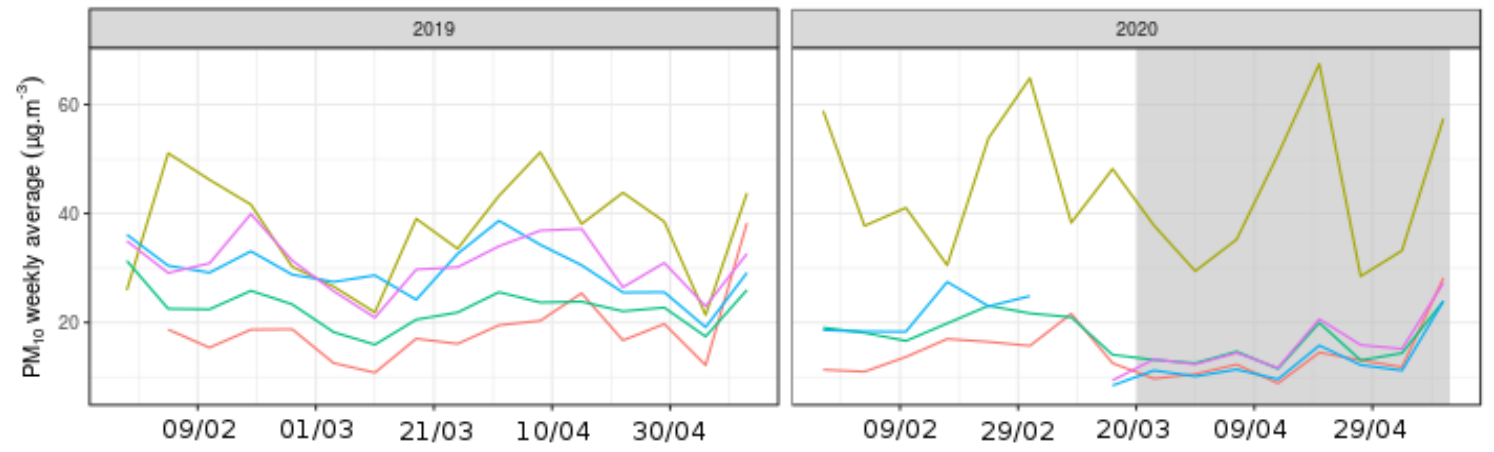

- DS

$-\llcorner M$

$-\mathrm{CN}$

- $\mathrm{CR}$

- LB

PM2.5
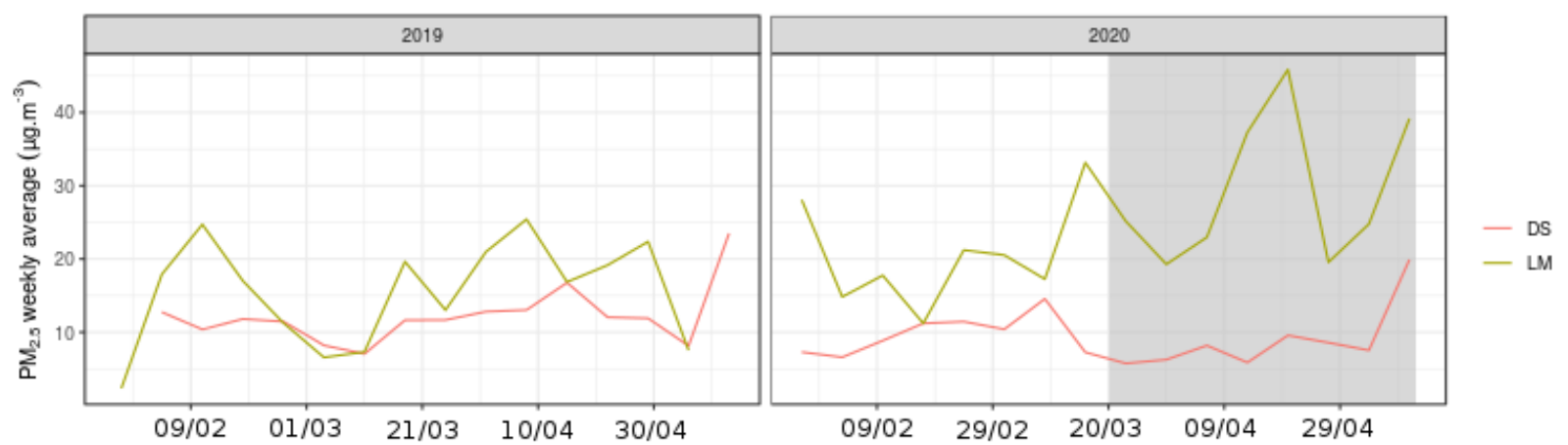

Fig. 3. Weekly average of ground-station measurements for $\mathrm{NO}_{2}, \mathrm{PM}_{10}$, and $\mathrm{PM}_{2.5}$ for Dock Sud (DS), La Matanza (LM), Centenario (CN), Cordoba (CR), and La Boca (LB) stations in the period analysed. The quarantine period is highlighted in gray.

located in an industrial area, where maximum values were detected during the night. For the same period of the year, $\mathrm{NO}_{2}$ concentrations fell by $61 \%>39 \%>32 \%>20 \%>11 \%$ for $\mathrm{LM}$, LB, CN, CR and DS stations. Similarly, PM 10 levels were $53 \%>48 \%>35 \%>32 \%$ lower for CR, LB, DS and $\mathrm{CN}$ stations. Here we also observed that $\mathrm{LM}$ has a different behavior, presenting an increase (64\% for $\mathrm{PM}_{2.5}$ and $8 \%$ for $\mathrm{PM}_{10}$ ) from the previous year in an identical period.

The reduction shown in our study is similar to the findings reported by Zambrano-Monserrate et al. (2020) and Nakada and Urban (2020). These differences guide us concerning the primary emission sources. A drastic reduction in lockdown context, where vehicle traffic declined, but industrial production remained active, points to the effect of mobile sources on measured pollutants.

$\mathrm{NO}_{2}$ and $\mathrm{PM}$ concentration values at all sites showed a sustained increase throughout the lockdown reaching significantly higher levels at the end of the period analyzed (late April-early May) than at the beginning. $\mathrm{NO}_{2}$ measurements at CR and DS were even higher than in 2019. Considering that restrictions were lifted during the last period, this may have generated an undesired effect of massive circulation, as it could be seen in other provinces of Argentina and several cities around the world. 
PM concentration values rose critically in 2020 at LM, implying a greater contribution from nearby emission sources, either industrial or non-industrial such as garbage burning or dust resuspension. These events are accentuated by a stable atmosphere condition that occurs mainly in the cold months, with many hours of calm wind during the night.

Finally, we compared the recorded values with the WHO air quality guidelines, intending to assess the impact of lockdown on air quality. The WHO recommends an hourly limit value of 200 $\mu \mathrm{g} \mathrm{m}^{-3}$ for $\mathrm{NO}_{2}$, and 24-hour averages of $50 \mu \mathrm{g} \mathrm{m}^{-3}$ and $25 \mu \mathrm{g} \mathrm{m}^{-3}$ for $\mathrm{PM}_{10}$ and $\mathrm{PM}_{2.5}$, respectively. $\mathrm{NO}_{2}$ concentrations did not exceed the guideline value during the period under review (maximum value: $154.2 \mu \mathrm{g} \mathrm{m}^{-3}$ at $\mathrm{CN}$ station, on February $8^{\text {th }}$ ). As for $\mathrm{PM}_{10}$, all five monitoring stations registered several exceedances. LM station was the one that exceeded most times for $\mathrm{PM}_{10}$ (maximum value: $118.3 \mu \mathrm{g} \mathrm{m}^{-3}$, on April $20^{\text {th }}$ ), and for $\mathrm{PM}_{2.5}$ (maximum value: $99.1 \mu \mathrm{g} \mathrm{m}^{-3}$, on April $\left.20^{\text {th }}\right)$. In this respect, other research studies have already pointed out the impact on air quality (Nakada and Urban, 2020; Sharma et al., 2020; Saadat et al., 2020; Tobías et al., 2020).

\subsection{Satellite Measurements}

We initially considered the $\mathrm{NO}_{2}$ satellite product at the location of the ground monitoring stations. Several comments can be made from this. First, the average $\mathrm{NO}_{2}$ column density obtained in 2 weeks exhibited similar behaviors for CN, CR, and LB stations, while at LM lower means of $\mathrm{NO}_{2}$ can be observed most of the time for years 2019 and 2020 (Fig. 4). In general, the LM station was significantly different from the rest of the stations (Fig. S1), which may be due to a lower background $\mathrm{NO}_{2}$ level.

In the first interval of time, from January $24^{\text {th }}$ to February $6^{\text {th }}$, low levels of $\mathrm{NO}_{2}$ were obtained (40-85 $\mu \mathrm{mol} \mathrm{m} \mathrm{m}^{-2}$ ). The scene is different in the second period. The parameter for every station except for LM started to grow in 2019, while it remained constant in 2020. The third period presented the higher means obtained in this study for the CN, CR, LB, and DS stations: 97$128 \mu \mathrm{mol} \mathrm{m}{ }^{-2}$ in 2019, and $125-158 \mu \mathrm{mol} \mathrm{m} \mathrm{m}^{-2}$ in 2020, while their standard deviations were nearly in the same order of averages. The fourth 2 -week period exhibited a remarkable decrease in 2019, probably because of the Carnival holiday. This decrease was negligible in 2020, although a high standard deviation was obtained for the same period (Fig. S1).

A marked decline of tropospheric $\mathrm{NO}_{2}$ column density means and standard deviations were observed from the fifth 2-week period in 2020 when the lockdown began strictly in the country. A reduction of around 54\% was observed at the urban CN, CR, and LB station sites, while at DS, it was $44 \%$, and there was an insignificant increase of $0.73 \%$ at LM location. Tobías et al. (2020) and Nakada and Urban (2020) also identified decreases in $\mathrm{NO}_{2}$ by remote sensing in cities where there was an outbreak quarantine for COVID-19. Meanwhile, 2019 data displayed a recovery of $\mathrm{NO}_{2}$ levels at the urban stations, slightly below those of the third period, an increase at LM, and a decrease at DS for the fifth period only. Finally, $\mathrm{NO}_{2}$ levels began to rise after day one of quarantine in the eighth 2-week period, corresponding to 1-14 May 2020, for every station location, in a range of $76.5-56.0 \mu \mathrm{mol} \mathrm{m}^{-2} \pm 25.3-47.7 \mu \mathrm{mol} \mathrm{m}{ }^{-2}$.

In a normal situation, the tropospheric $\mathrm{NO}_{2}$ column is manly placed over the AMBA (Fig. 5).
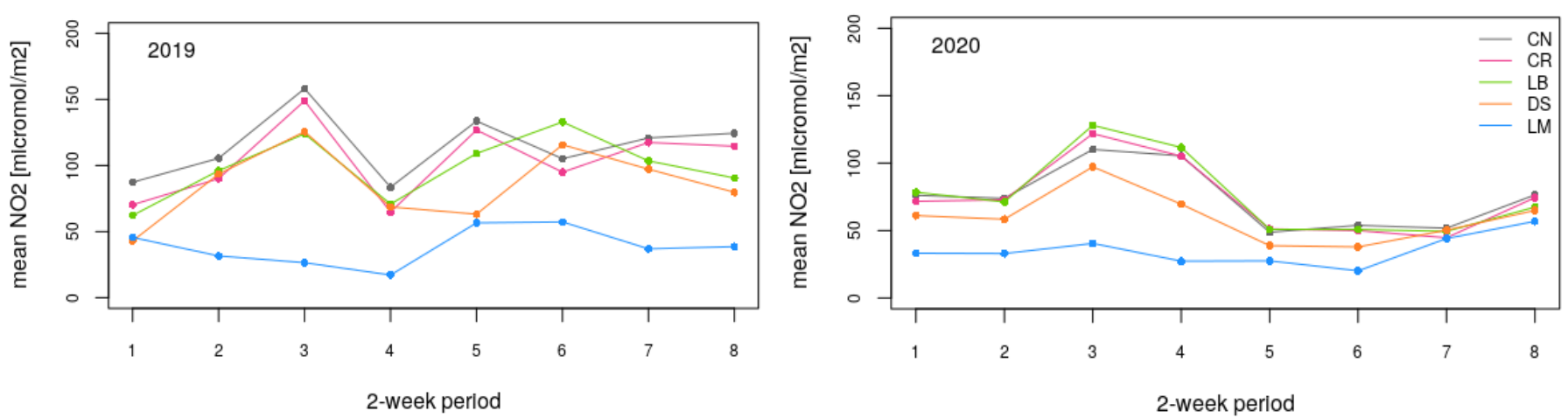

Fig. 4. Nitrogen dioxide 2 -week means at the monitoring stations locations, obtained by TROPOMI/Sentinel-5p. The fifth 2 -week period corresponds to the one starting at the lockdown date in Argentina. 


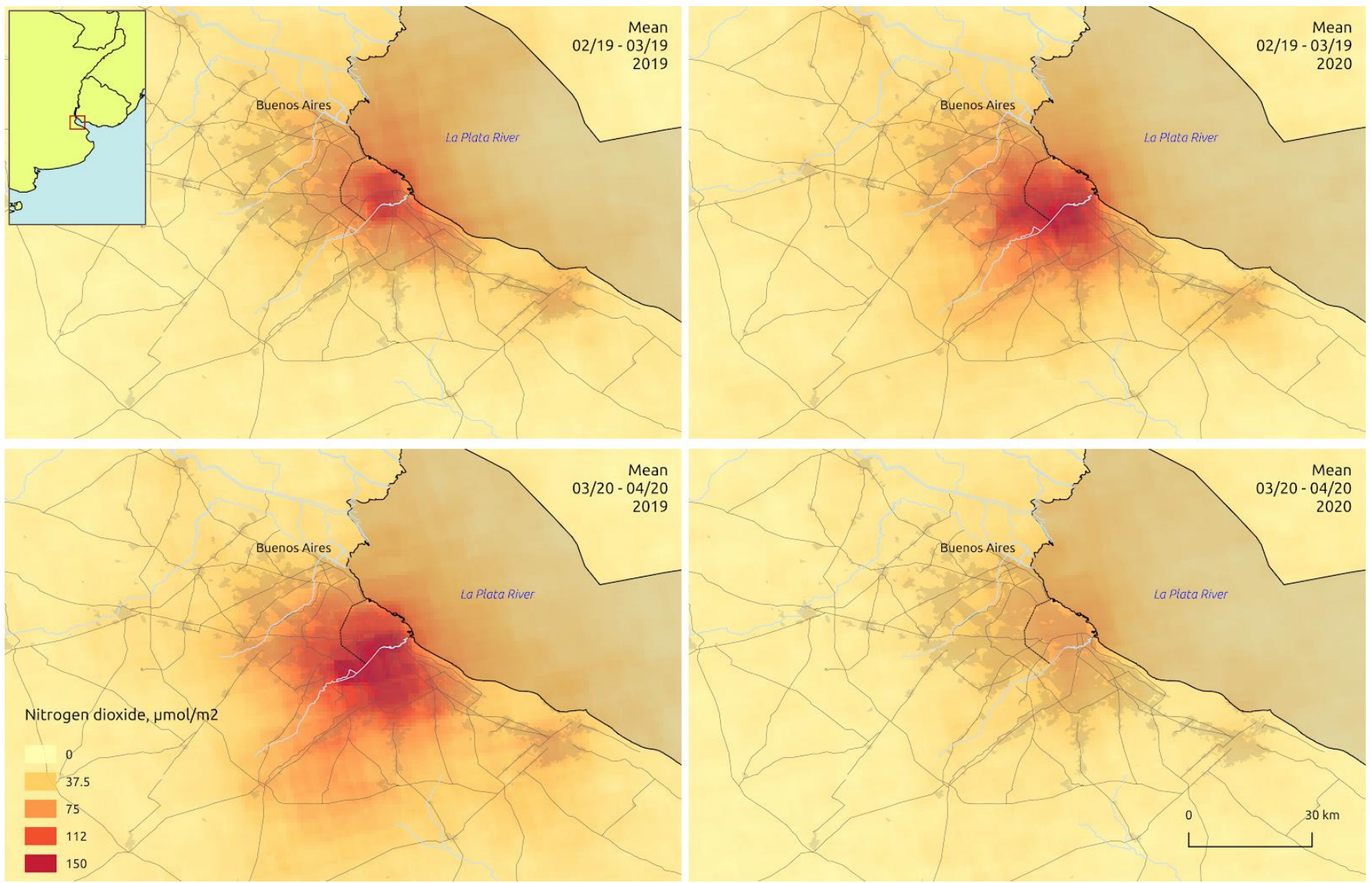

Fig. 5. Mean levels of tropospheric $\mathrm{NO}_{2}$ measured by the TROPOMI/Sentinel-5p (ESA) before and during the lockdown in Buenos Aires, Argentina, compared to the same period in 2019.

Furthermore, data analyzed revealed that: a) the monthly mean of $\mathrm{NO}_{2}$ in the period from February $19^{\text {th }}$ to March $19^{\text {th }}$ in 2019 was lower than the period from March $20^{\text {th }}$ to April $20^{\text {th }}$ in the same year, and this might be due to a four-day holiday during Carnival and the summer holidays; b) $\mathrm{NO}_{2}$ increased for the period from February $19^{\text {th }}$ to March $19^{\text {th }}$ in 2019 and 2020; c) the monthly average of $\mathrm{NO}_{2}$ obtained for the lockdown period showed a clear reduction in AMBA.

The 2-week means of AOD retrieved at the monitoring stations showed similar behaviors for all stations, with relatively lower values at LM and DS stations compared to CN, CO, LB for 2019 and 2020 (Fig. 6). Mean AOD values retrieved at LM and DS stations were in the range of 0.040.17 , similar for 2019 and 2020, except for the third 2-week periods in 2020 where values were increased ( 0.21 and 0.22 for DS and LM, respectively).

Concerning $A O D$ values retrieved at $\mathrm{CN}, \mathrm{CO}$, and $\mathrm{LB}$, a decrease was observed when comparing the first four 2-week periods and the last four 2-week periods for both 2019 (range 0.15-0.31 and $0.09-0.22$, respectively) and 2020 (range $0.24-0.40$ and $0.13-0.19$, respectively). This decrease was more pronounced in 2020 when the lockdown was established from the fifth 2week period onwards than 2019. In fact, between the fourth and fifth 2-week periods, we noticed a decrease of 38-66\% during 2020. From the fifth 2-week period, standard deviations for 2020 had a significant decrease compared to 2019 (Fig. S2).

The decline in AOD in 2020 coincided with the reduction of PM surface measurements described above. As an exception, $\mathrm{LM}$ did not show a reduction in $\mathrm{PM}_{10}$ and $\mathrm{PM}_{2.5}$, but a decrease in $A O D$ was observed. It must be considered that $A O D$ is an adimensional parameter that comprises the aerosols in the whole atmospheric column with a spatial resolution of $1 \mathrm{~km}$. At the same time, PM stations measure the concentration of surface aerosols at a limited spatial range. Aerosol distribution in the atmospheric column is a determining parameter of the AOD-PM relationship (Li et al., 2015). Moreover, satellite observations corresponded to a particular time of the day, while PM concentrations considered in this study were a 24-hour mean. 

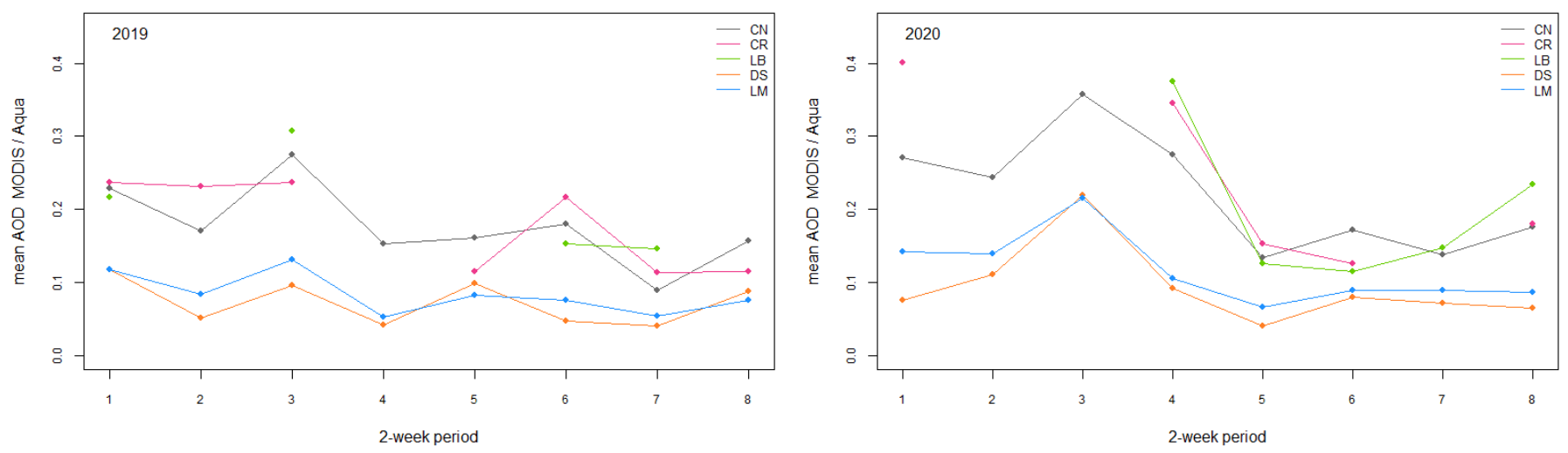

Fig. 6. Aerosol Optical Depth (AOD $470 \mathrm{~nm}$ ) 2-week means at the monitoring stations locations obtained by MODIS/Aqua. The fifth 2-week period corresponds to the one starting at the lockdown date in Argentina.
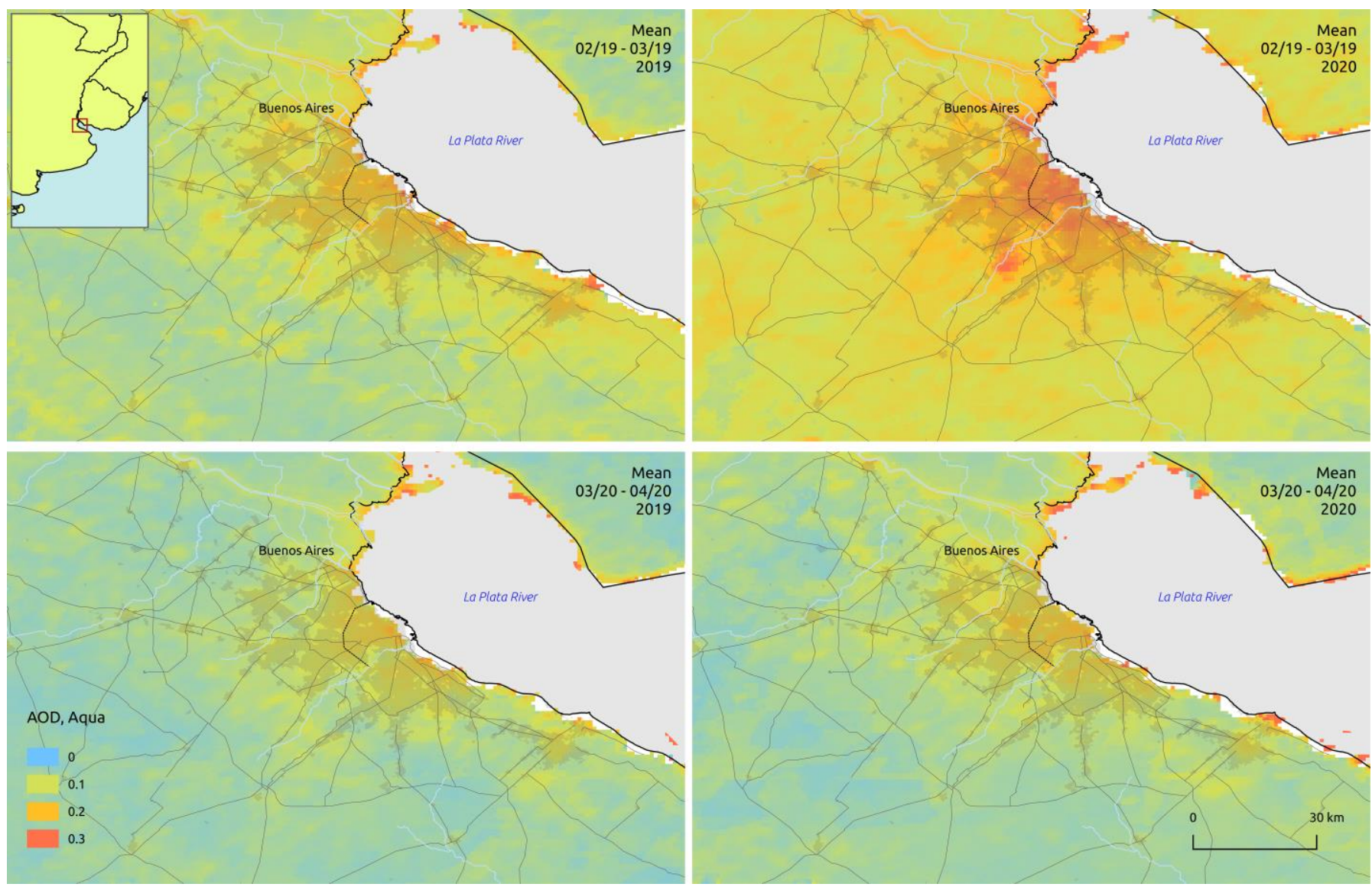

Fig. 7. Aerosol Optical Depth (AOD) at $470 \mathrm{~nm}$ Mean levels AOD measured by the MODIS/Aqua + Terra-NASA before and during the lockdown in Buenos Aires, Argentina, compared to the same period in 2019.

The spatial distribution of $A O D$ at the study area (Fig. 7) showed that, as observed for tropospheric $\mathrm{NO}_{2}$ column density, $\mathrm{AOD}$ mean values for the period February $19^{\text {th }}-$ March $19^{\text {th }}$ in 2020 were higher than for 2019. Moreover, a greater spatial extension of higher AOD values for 2020 was observed during this monthly pre-lockdown period. The monthly average of AOD in the period February $19^{\text {th }}$ to March $19^{\text {th }}$ was higher than for the last period (March $20^{\text {th }}-$ April $20^{\text {th }}$ ) for both years. AOD decreased more sharply for the period March $20^{\text {th }}$ to April $20^{\text {th }}, 2020$ than for 2019, which is consistent with the lockdown.

Similarly, Ranjan et al. (2020) detected a substantial AOD reduction in India. Filonchyk et al. 
(2020) observed high AOD values spatially associated with high $\mathrm{NO}_{2}$ concentrations over eastern China. The association between changes in $\mathrm{NO}_{2}$ and $\mathrm{AOD}$ caused by the lockdown was also analyzed in Kumar (2020).

Daily retrieves of $\mathrm{NO}_{2}$ and $\mathrm{AOD}$ displayed a dramatic reduction in the first days of lockdown, evidencing the fast elimination of $\mathrm{NO}_{2}$ and aerosols from the atmosphere since the restriction of vehicular traffic. Nevertheless, it is noteworthy that the residence time of aerosols in the atmosphere is much longer, in contrast to several hours for $\mathrm{NO}_{2}$ (Filonchyk et al., 2020).

\section{CONCLUSIONS}

In Argentina there is a lack of public policies aimed at controlling vehicle emissions. The COVID-19 pandemic lockdown, which began on March $20^{\text {th }}, 2020$, reduced traffic flow by almost $80 \%$. This exceptional minimal vehicular circulation allowed us to evaluate the atmospheric baseline composition of relevant atmospheric pollutants $\left(\mathrm{NO}_{2}, \mathrm{PM}_{10}\right.$ and $\left.\mathrm{PM}_{2.5}\right)$ using ground and satellite data. Ground-based measurements of the three pollutants showed a sharp drop at the beginning of lockdown. Consistently, means and standard deviations of tropospheric $\mathrm{NO}_{2}$ column density and AOD declined when the lockdown began strictly in Argentina. These changes clearly indicate the negative contribution of vehicle transport to air quality in AMBA. Finally, we demonstrated the complementarity of ground-based and satellite data measurements. Changes in the atmospheric composition of $\mathrm{NO}_{2}$ for this exceptional situation in cities without ground-based air pollution monitoring would be possible with satellite data.

\section{ACKNOWLEDGMENTS}

The authors gratefully acknowledge the Matanza-Riachuelo Basin Authority (ACUMAR), the National Weather Service (SMN), and the General Direction of Institutional Quality and Open Government of the City of Buenos Aires for providing data for the study. We also appreciate the support of the Comisión Nacional de Actividades Espaciales (CONAE), the Argentinian space agency and the Scientific and Technical Research Council (CONICET).

\section{SUPPLEMENTARY MATERIAL}

Supplementary data associated with this article can be found in the online version at https://doi.org/10.4209/aaqr.2020.07.0486

\section{REFERENCES}

Abrutzky, R., Ibarra, S., Matus, P., Romero-Lankao, P., Pereyra, V., Dawidowski, L. (2013). Atmospheric pollution and mortality. A comparative study between two Latin American cities: Buenos Aires (Argentina) and Santiago (Chile). Int. J. Environ, 6, 363-380. https://doi.org/10.15 04/IJENVH.2013.056977

Atkinson, R.W., Butland, B.K., Anderson, H.R., Maynard, R.L. (2018). Long-term concentrations of nitrogen dioxide and mortality: A meta-analysis of cohort Studies. Epidemiology 29, 460-472. https://doi.org/10.1097/ede.0000000000000847

Atkinson, R.W., Mills, I.C., Walton, H.A., Anderson, H.R. (2015). Fine particle components and health-a systematic review and meta-analysis of epidemiological time series studies of daily mortality and hospital admissions. J. Exposure Sci. Environ. Epidemiol. 25, 208-214. https://doi.org/10.1038/jes.2014.63

Bai, Y., Yao, L., Wei, T., Tian, F., Jin, D.Y., Chen, L., Wang, M. (2020). Presumed asymptomatic carrier transmission of COVID-19. JAMA 323, 1406-1407. https://doi.org/10.1001/jama.2020. 2565

Bauwens, M., Compernolle, S., Stavrakou, T., Müller, J.F., van Gent, J., Eskes, H., Levelt, P.F., van der A.R., Veefkind, J.P., Vlietinck, J., Yu, H., Zehner, C. (2020). Impact of coronavirus outbreak on $\mathrm{NO}_{2}$ pollution assessed using TROPOMI and OMI observations. Geophys. Res. Lett. 47, 
e2020GL087978. https://doi.org/10.1029/2020GL087978

Borge, R., Requia, W.J., Yagüe, C., Jhun, I., Koutrakis, P. (2019). Impact of weather changes on air quality and related mortality in Spain over a 25 year period [1993-2017]. Environ. Int. 133, 105272. https://doi.org/10.1016/j.envint.2019.105272

Brunekreef, B. (2007) Health effects of air pollution observed in cohort studies in Europe. J. Exposure Sci. Environ. Epidemiol. 17, S61-S65. https://doi.org/10.1038/sj.jes.7500628

Burnett, R.T., Stieb, D., Brook, J.R., Cakmak, S., Dales, R., Raizenne, M., Vincent, R., Dann, T. (2004). Associations between short-term changes in nitrogen dioxide and mortality in Canadian cities. Arch. Environ. Health 59, 228-236. https://doi.org/10.3200/AEOH.59.5.228-236

Cadelis, G., Tourres, R., Molinie, J. (2014). Short-term effects of the particulate pollutants contained in Saharan dust on the visits of children to the emergency department due to asthmatic conditions in Guadeloupe (French Archipelago of the Caribbean). PLoS One 9, e91136. https://doi.org/10.1371/journal.pone.0091136

Camilloni, I., Barrucand, M. (2012). Temporal variability of the Buenos Aires, Argentina, urban heat island. Theor. Appl. Climatol. 107, 47-58. https://doi.org/10.1007/s00704-011-0459-z

Cohen, A.J., Brauer, M., Burnett, R., Anderson, H.R., Frostad, J., Estep, K., Balakrishnan, K., Brunekreef, B., Dandona, L., Dandona, R., Feigin, V. (2017). Estimates and 25-year trends of the global burden of disease attributable to ambient air pollution: An analysis of data from the Global Burden of Diseases Study 2015. Lancet, 389, 1907-1918. https://doi.org/10.1016/S01406736(17)30505-6

Collivignarelli, M.C., Abbà, A., Bertanza, G., Pedrazzani, R., Ricciardi, P., Miino, M.C. (2020). Lockdown for CoViD-2019 in Milan: What are the effects on air quality? Sci. Total Environ. 732, 139280. https://doi.org/10.1016/j.scitotenv.2020.139280

Correia, A.W., Pope III, C.A., Dockery, D.W., Wang, Y., Ezzati, M., Dominici, F. (2013). The effect of air pollution control on life expectancy in the United States: An analysis of 545 US counties for the period 2000 to 2007. Epidemiology 24, 23-31. https://doi.org/10.1097/EDE.0b013e31 82770237

Dongarrà, G., Manno, E., Varrica, D., Lombardo, M., Vultaggio, M. (2010). Study on ambient concentrations of $\mathrm{PM}_{10}, \mathrm{PM}_{10-2.5}, \mathrm{PM}_{2.5}$ and gaseous pollutants. Trace elements and chemical speciation of atmospheric particulates. Atmos. Environ. 44: 5244-5257. https://doi.org/10.10 16/j.atmosenv.2010.08.041

Duncan, B.N., Prados, A.I., Lamsal, L.N., Liu, Y., Streets, D.G., Gupta, P., Hilsenrath, E., Kahn, R.A., Nielsen, J.E., Beyersdorf, A.J., Burton, S.P. (2014). Satellite data of atmospheric pollution for U.S. air quality applications: Examples of applications, summary of data end-user resources, answers to FAQs, and common mistakes to avoid. Atmos. Environ. 94, 647-662. https://doi.org/10.1016/j.atmosenv.2014.05.061

Ferreroa, F., Abrutzkyb, R., Ossorioc, M.F., Torresc, F. (2019). Efectos de la contaminación y el clima en las consultas pediátricas por infección respiratoria aguda en la Ciudad de Buenos Aires. Arch. Argent. Pediatr, 117, 368-374.

Filonchyk, M., Hurynovich, V., Yan, H., Gusev, A., Shpilevskaya, N. (2020). Impact assessment of COVID-19 on variations of $\mathrm{SO}_{2}, \mathrm{NO}_{2}, \mathrm{CO}$ and $\mathrm{AOD}$ over east China. Aerosol Air Qual. Res, 20, 1530-1540. https://doi.org/10.4209/aaqr.2020.05.0226

Goldstone, M.E. (2015). Review of evidence on health aspects of air pollution-REVIHAAP project. Air Qual Atmos Health, 49: 35.

Instituto Nacional de Estadísticas y Censos (INDEC) (2011). Censo Nacional de Población, Hogares y Viviendas 2010. http://www.censo2010.indec.gov.ar/ (accessed 31 March 2020).

Kumar, S. (2020). Effect of meteorological parameters on spread of COVID-19 in India and air quality during lockdown. Sci. Total Environ. 745, 141021. https://doi.org/10.1016/j.scitotenv. 2020.141021

Lelieveld, J., Evans, J.S., Fnais, M., Giannadaki, D., Pozzer, A. (2015). The contribution of outdoor air pollution sources to premature mortality on a global scale. Nature 525, 367-371. https://doi.org/10.1016/j.scitotenv.2020.141021

Li, J., Carlson, B.E., Lacis, A.A. (2015). How well do satellite AOD observations represent the spatial and temporal variability of $\mathrm{PM}_{2.5}$ concentration for the United States? Atmos. Environ. 102, 260-273. https://doi.org/10.1016/j.atmosenv.2014.12.010

Lyapustin, A., Martonchik, J., Wang, Y., Laszlo, I., Korkin, S. (2011a). Multiangle implementation 
of atmospheric correction (MAIAC): 1. Radiative transfer basis and look-up tables. J. Geophys. Res. 116, D03210. https://doi.org/10.1029/2010JD014985

Lyapustin, A., Wang, Y., Laszlo, I., Kahn, R., Korkin, S., Remer, L., Levy, R., Reid, J.S. (2011b). Multiangle implementation of atmospheric correction (MAIAC): 2. Aerosol algorithm. J. Geophys. Res. 116, D03211. https://doi.org/10.1029/2010JD014986

Mannucci, P.M., Franchini, M. (2017). Health effects of ambient air pollution in developing countries. Int. J. Environ. Res. Public Health 14, 1048. https://doi.org/10.3390/ijerph14091048

Ministerio de Salud (2020). Informe diario. https://www.argentina.gob.ar/coronavirus/informediario (accessed 31 March 2020).

Mukherjee, A., Agrawal, M. (2018). A global perspective of fine particulate matter pollution and its health effects, in: de Voogt, P. (Ed.), Reviews of Environmental Contamination and Toxicology Volume 244, Springer International Publishing, Cham, pp. 5-51. https://doi.org/10. 1007/398_2017_3

Nakada, L.Y.K., Urban, R.C. (2020). COVID-19 pandemic: Impacts on the air quality during the partial lockdown in São Paulo state, Brazil. Sci. Total Environ. 730, 139087. https://doi.org/10. 1016/j.scitotenv.2020.139087

Ranjan, A.K., Patra, A.K., Gorai, A.K. (2020). Effect of lockdown due to SARS COVID-19 on aerosol optical depth (AOD) over urban and mining regions in India. Sci. Total Environ. 745, 141024. https://doi.org/10.1016/j.scitotenv.2020.141024

Represa, N.S. (2020). Elaboración e implementación de una propuesta metodológica para la evaluación y gestión de la calidad del aire mediante el enfoque de la ciencia de datos (Doctoral dissertation).

Saadat, S., Rawtani, D., Hussain, C.M. (2020). Environmental perspective of COVID-19. Sci. Total Environ. 728, 138870. https://doi.org/10.1016/j.scitotenv.2020.138870

Samoli, E., Aga, E., Touloumi, G., Nisiotis, K., Forsberg, B., Lefranc, A., Pekkanen, J., Wojtyniak, B., Schindler, C., Niciu, E., Brunstein, R. (2006). Short-term effects of nitrogen dioxide on mortality: An analysis within the APHEA project. Eur. Respir. J. 27, 1129-1138. https://doi.org/10.1183/ 09031936.06.00143905

Schwela, D. (2000). Air pollution and health in urban areas. Rev. Environ. Health 15, 13-42. https://doi.org/10.1515/REVEH.2000.15.1-2.13

Seinfeld, J.H., Pandis, S.N. (2016). Atmospheric chemistry and physics: From air pollution to climate change. John Wiley \& Sons.

Sharma, S., Zhang, M., Gao, J., Zhang, H., Kota, S.H. (2020). Effect of restricted emissions during COVID-19 on air quality in India. Sci. Total Environ. 728, 138878. https://doi.org/10.1016/j.sci totenv.2020.138878

Tobías, A., Carnerero, C., Reche, C., Massagué, J., Via, M., Minguillón, M.C., Alastuey, A., Querol, $X$. (2020). Changes in air quality during the lockdown in Barcelona (Spain) one month into the SARS-CoV-2 epidemic. Sci. Total Environ. 726, 138540. https://doi.org/10.1016/j.scitotenv.202 0.138540

United States Environmental Protection Agency (U.S. EPA) (2008). Integrated Science Assessment (ISA) for Nitrogen Dioxide - Health Criteria. United States Environmental Protection Agency.

Veefkind, J.P., Aben, I., McMullan, K., Förster, H., De Vries, J., Otter, G., Claas, J., Eskes, H.J., De Haan, J.F., Kleipool, Q., Van Weele, M. (2012). TROPOMI on the ESA Sentinel-5 Precursor: A GMES mission for global observations of the atmospheric composition for climate, air quality and ozone layer applications. Remote Sens. Environ. 120, 70-83. https://doi.org/10.1016/j.rs e.2011.09.027

World Health Organization (WHO) (2010). Environment and health risks: A review of the influence and effects of social inequalities. WHO Regional Office for Europe, Denmark.

Zambrano-Monserrate, M.A., Ruano, M.A., Sanchez-Alcalde, L. (2020). Indirect effects of COVID19 on the environment. Sci. Total Environ. 728, 138813. https://doi.org/10.1016/j.scitotenv.2 020.138813

Zhang, R., Wang, G., Guo, S., Zamora, M.L., Ying, Q., Lin, Y., Wang, W., Hu, M., Wang, Y. (2015). Formation of urban fine particulate matter. Chem. Rev. 115, 3803-3855. https://doi.org/10.10 21/acs.chemrev.5b00067 